\title{
IMMOBILE TRACE ELEMENTS DISCRIMINATION DIAGRAMMS WITH ZEOLITIZED VOLCANICLASTICS FROM THE EVROS - THRACE - RHODOPE VOLCANIC TERRAIN
}

\author{
Kitsopoulos K. \\ University of Leicester, Department of Geology, University Road, LE1 7RH Leicester, UK, \\ kitsopoulos.k@gmail.com
}

\begin{abstract}
The Rhodope and Evros areas of the Thrace Region in north-eastern Greece and the adjusted areas in Bulgaria are characterized by wide spread volcanic formations of Upper Eocene to Miocene in age. The volcaniclastic materials associated with such formations have, in some cases, undergone inter alia a notable zeolitization process. The mineralogy of the altered volcaniclastics is often dominated by clinoptilolite heulandite type of minerals. The Winchester and Floyd (1977) plots indicating rhyodacite/dacite to trachyandesite parent materials, while the similar diagram, as modified by Pearce (1986), indicate andesite to trachyandesite precursors. The alkalinity index ( $\mathrm{Nb} / \mathrm{Y}$ ratio) seems to coincide between the two types of diagrams, but, there is a notable difference of the differentiation index, i.e. the $\mathrm{Zr} / \mathrm{TiO} 2$ ratio. The Th-Co diagram (Hastie et al., 2007) unfolds a clearer picture for the nature of the precursors and reveals a clear progression of a calc-alkaline to a high-K calc alkaline affinity of the parental volcanic materials.
\end{abstract}

Key words: volcaniclastics, zeolitization, zeolite minerals, geochemical classification, trace elements, Thrace - Evros, Greece.

\section{Introduction}

Zeolite minerals, such as clinoptilolite and mordenite, are often found worldwide as alteration products in volcaniclastic materials. It is known that the zeolitization involves a diffusion-controlled hydration, mainly of volcanic glass, and an alkali ion exchange procedure. As a result, the zeolitization involves the relative gain and losses of elements initially present, especially alkaline and alkali earths and sometimes Si too. So, because of their zeolitization, these materials usually do not attract any considerable petrological attention, especially on their geochemical nature. The truth is that under this situation, the geochemical nature of the parent materials is extremely difficult to establish. The indiscriminate use of geochemical classification diagrams is not recommended.

The objective of the present study was to choose and apply the most appropriate geochemical tools, for zeolitized rocks, i.e. altered materials, with an ultimate scope to examine their geochemical characteristics and to verify the nature of the parent volcaniclastc materials (i.e. the nature of the precursors for the formation of zeolites).

\section{Geological setting}

The geological structure of the Western Thrace - Evros area of Greece consists of three distinct units: 
1. The Pre - Mesozoic crystalline basement which consist of a high grade metamorphic rocks, such as marbles, gneisses, amphibolites and pegmatites (lower allochthonous unit) to schistand amphibolitic- gneisses and amhibolites (upper autochthonous unit).

2. The Circum-Rhodope Zone, which, in the wider Thrace and Evros areas, consist of two parts, the Makri Unit and the Drymos-Melia Series.

3. Tertiary basins which are built from: a) volcanic rocks, such as granite bodies, sills and dykes, b) volcaniclastic materials such as tuffs, breccias and lahars, and c) sediments and sedimentary rocks such as conglomerates, sandstones, marls, sandy marls and locally lignite seams. The magmatic activity, of Eocene to Oligocene age is related continental collision that followed the subduction of African - Arabian plate beneath the Eurasian (Yanev et. al. 1998). Marchev et al (2004) have compiled a map of the geology of the Eastern Rhodope area (Figure 1).

\section{Materials and Methods}

\subsection{Materials}

The samples we used are zeolite-bearing volcaniclastic materials from the wider Evros - Thrace Rhodope volcanic terrain of Greece. Typical examples of such type of alteration have been recorded in numerous locations in the above mentioned areas of north-eastern Greece, (Figure 2), as well as in south and southeast Bulgaria (Tsirambides et al., 1989; Kirov et al., 1990; Tsolis-Katagas and Katagas, 1990; Kitsopoulos, 1991; Skarpelis et al., 1993; Djourova and Aleksiev, 1995; Stamatakis et al., 1998; Marantos et al., 2004).

\subsection{XRD and XRF}

Since the mineralogy of the zeolitized materials of the Tertiary basins of the Thrace - Evros area has been examined in many occasions in the past (Tsirambides et al., 1989; Kirov et al., 1990; TsolisKatagas and Katagas, 1990; Skarpelis et al., 1993; Djourova and Aleksiev, 1995; Stamatakis et al., 1998; Marantos et al., 2004), the XRD method was applied, with the sole purpose to confirm the presence of zeolite minerals in the samples chosen to be examined.

The geochemistry was examined by using a PANalytical Axios Advanced PW4400 XRF spectrometer, fitted with a 4kW Rh anode SST-mAX X-Ray tube. Major elements determined on fused glass beads prepared from ignited powders sample to flux ratio 1:5, 80\% Li metaborate: $20 \% \mathrm{Li}$ tetraborate flux. Trace elements analysed on $32 \mathrm{~mm}$ diameter pressed powder briquettes prepared from $10 \mathrm{~g}$ fine ground powder mixed with ca 20-25 drops 7\% PVA soln and pressed at 10 tons per square inch. Various international standards, as recorded in GeoRem (Jochum et al., 2005, http://georem.mpch-mainz.gwdg.de), were run with the samples as control on the quality of the analyses.

\section{Data}

\section{Data 4.1}

The XRD analysis has confirmed the presence, in various amounts, of zeolite minerals in the samples studied. There was no evidence found in their mineralogy in line with any influence of any other significant alteration, i.e. hydrothermal.

Some representative data, on $\mathrm{TiO}_{2}, \mathrm{Nb}, \mathrm{Zr}$, Y, Th and Co values from the XRF analyses of the zeolitized volcaniclastics are given in Table 1. 


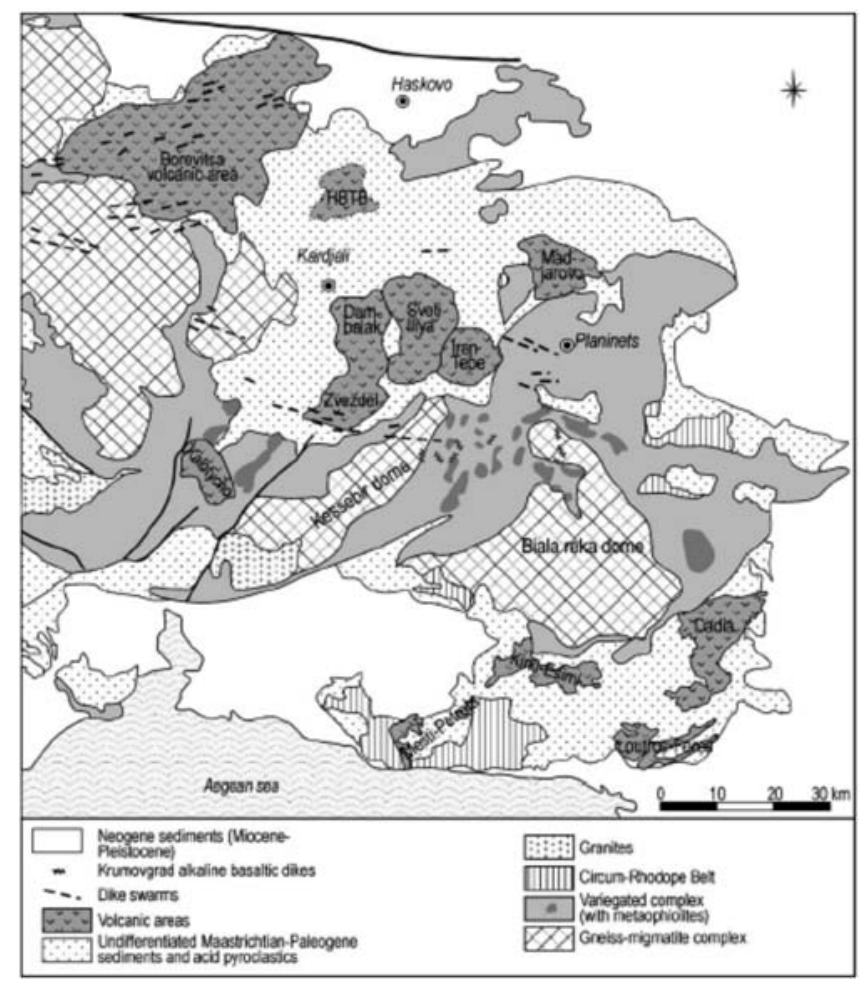

Fig. 1 : Schematic map of the geological structure of Eastern Rhodope (Marchev et al., 2004).

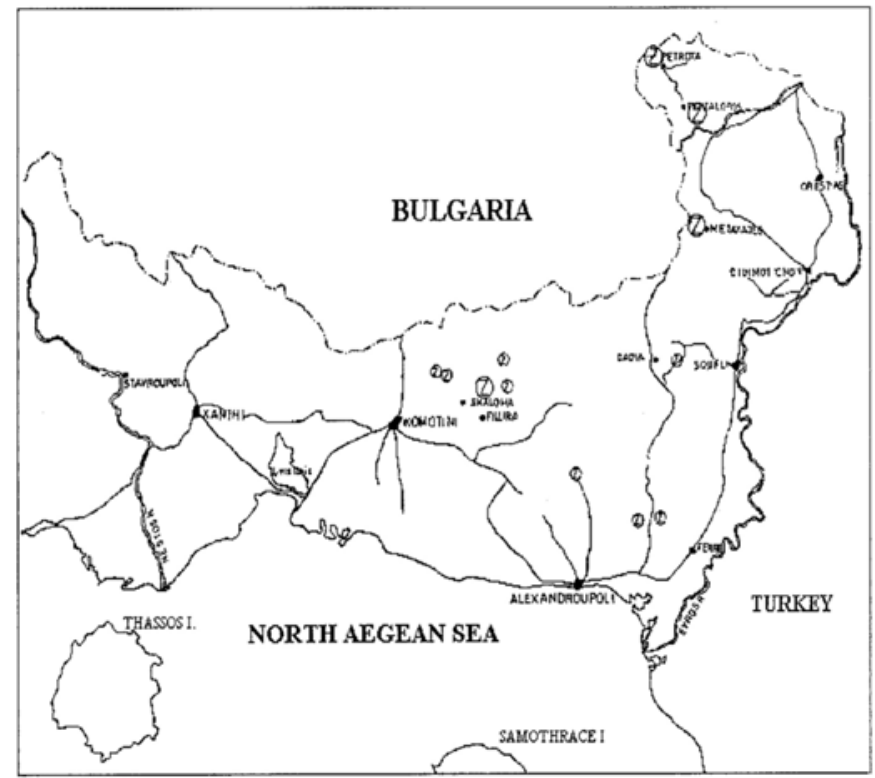

Fig. 2 : Zeolite deposits (Z) and occurrences (z) in Thrace (north eastern Greece), scale 1:1.000.000 (Marantos et al., 2000). 
Table 1.

\begin{tabular}{|c|c|c|c|c|c|c|c|}
\hline Sample & Locality & $\mathrm{TiO}_{2}$ & $\mathrm{Nb}$ & $\mathrm{Zr}$ & $\mathrm{Y}$ & $\mathrm{Th}$ & Co \\
\hline & & $\%$ & \multicolumn{5}{|c|}{$\mathrm{ppm}$} \\
\hline M1 & Metaxades & 0.11 & 28.1 & 60.8 & 34.9 & 21.6 & 0.9 \\
\hline M2 & Metaxades & 0.09 & 27.7 & 65.9 & 28.4 & 22.7 & 0.9 \\
\hline L1 & Lefkimi - Dadia & 0.13 & 10.2 & 87.8 & 12.0 & 15.8 & $0 . .8$ \\
\hline L2 & Lefkimi - Dadia & 0.18 & 8.4 & 91.6 & 18.6 & 14.1 & 3.0 \\
\hline P1 & Petrota & 0.16 & 21.9 & 145.9 & 16.5 & 30.9 & 0.8 \\
\hline P2 & Petrota & 0.17 & 26.6 & 166.8 & 22.2 & 38.3 & 0.8 \\
\hline F1 & Ferres & 0.14 & 8.9 & 65.4 & 13.1 & 12.9 & 1 \\
\hline F2 & Ferres & 0.40 & 6.3 & 136.2 & 13.1 & 12.3 & 5 \\
\hline
\end{tabular}

The classic $\mathrm{SiO}_{2}$ vs. $\mathrm{K}_{2} \mathrm{O}$ (Peccerillo \& Taylor, 1976; Rickwood, 1989) and the $\mathrm{SiO}_{2}$ vs. $\mathrm{Na}_{2} \mathrm{O}+\mathrm{K}_{2} \mathrm{O}$ (Le Maitre et al., 1989, 1992) diagrams have been proved unusable with zeolitized materials (Kitsopoulos et al., 2001). In these cases the problems occurred are related to the mobilisation and the redistribution of the alkalis during the zeolitization process. An alternative approach to establish the nature of the parent materials is to use immobile trace elements. As a proxy to the TAS diagram, a discrimination diagram, based on immobile elements, was proposed, which uses the $\mathrm{Nb} / \mathrm{Y}$ vs. $\mathrm{Zr} / \mathrm{TiO}_{2}$ ratios (Winchester and Floyd, 1977). The Ti, Zr, Nb and $\mathrm{Y}$ are considered immobile during post-consolidation alteration and metamorphic processes. In the Winchester and Floyd, the $\mathrm{Zr} / \mathrm{TiO}{ }_{2}$ ratio can primarily act as a differentiation index, as the differentiation of a basaltic magma can be traced by the decrease of $\mathrm{TiO}_{2}$, and to a less extent as an alkalinity index, as $\mathrm{Zr}$ tends to concentrate in alkaline rocks. The $\mathrm{Nb} / \mathrm{Y}$ ratio acts only as an alkalinity index (Pearce and Cann 1973,) which corresponds with the higher concentrations of $\mathrm{Nb}$ in alkaline provinces. The field boundaries of the diagram should be viewed as marking gradational changes rather than sharply defined fields. Also, it should be always taken into account that the diagram was prepared using all types of igneous rocks except for island arc lavas. As the original plot by Winchester and Floyd (1977) has been designed prior to the publication of the TAS diagram by Le Bas et al. $(1986,1992)$, the field definition has been subsequently modified by Pearce (1996) who used a much larger dataset and also statistically drawn boundaries. The diagram used volcanic arc analyses but it poses the problem of a large overlap displayed by island arc basalts, basaltic andesites, andesites and dacites.

\section{Discussion - Conclusions}

By using the Winchester and Floyd (1977) it can be seen that the samples examined plot in the field of rhyodacite/dacite to trachyandesite, with one sample be plotted as trachyte (Fig. 3). On the similar diagram as modified by Pearce (1986) they plot on the field of andesite to trachyandesite (Figure 4). Although the alkalinity index ( $\mathrm{Nb} / \mathrm{Y}$ ratio) seems to coincide between the two plots, there is a notable difference of the differentiation index of these plots, i.e. the $\mathrm{Zr} / \mathrm{TiO}_{2}$ ratio.

Koutles et al. (1995) examined the geochemistry of a single zeolitized outcrop, the Metaxades deposit, by using samples which were collected on a vertical mode, of a traverse of visible thickness of 100m, in the Metaxades quarry. Their results are plotted in the Winchester and Floyd (1977) and the similar, but modified, by Pearce (1986) (Figs 5 \& 6). 


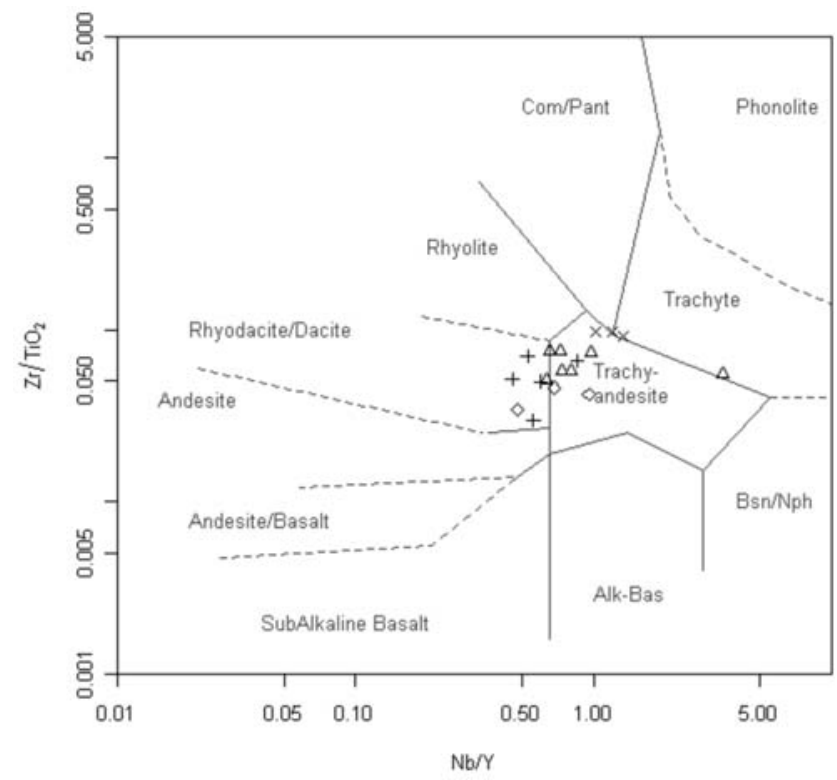

Fig. 3: $\mathrm{Nb} / \mathrm{Y}$ vs. $\mathrm{Zr} / \mathrm{TiO} 2$ plot of $\mathrm{XRF}$ analyses of zeolitized materials on the diagram by Winchester and Floyd (1977). +: Dadia-Lefkimi, $\Delta$ : Metaxades, X: Petrota, $\diamond$ : Ferres.

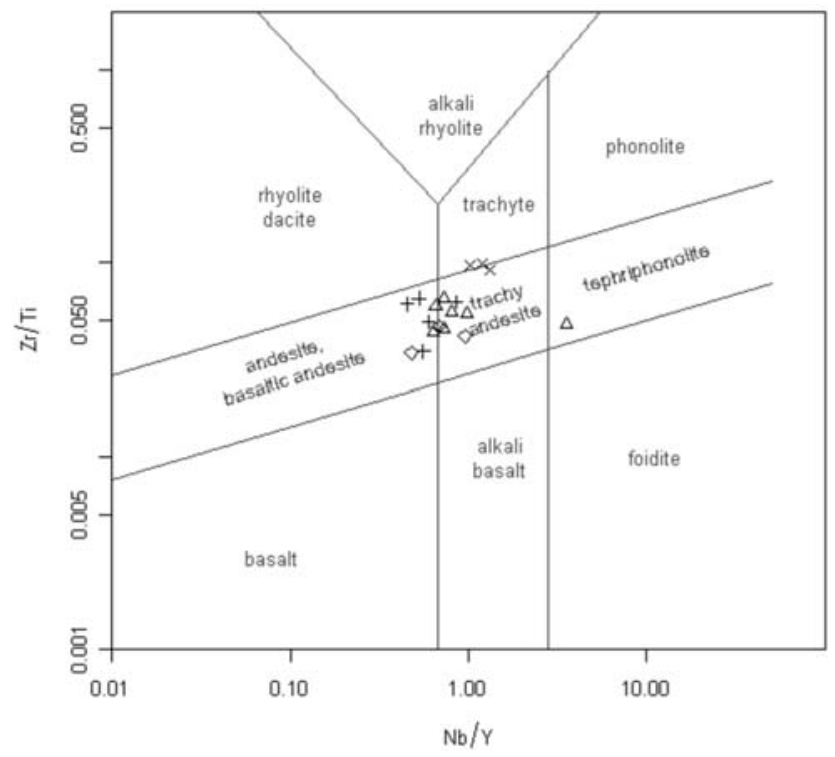

Fig. 4: $\mathrm{Nb} / \mathrm{Y}$ vs. $\mathrm{Zr} / \mathrm{Ti}$ plot of $\mathrm{XRF}$ analyses of zeolitized materials on the diagram by Winchester and Floyd (1977), as modified by Pearce (1986). +: Dadia-Lefkimi, $\Delta$ : Metaxades, X: Petrota, $\diamond$ : Ferres. 


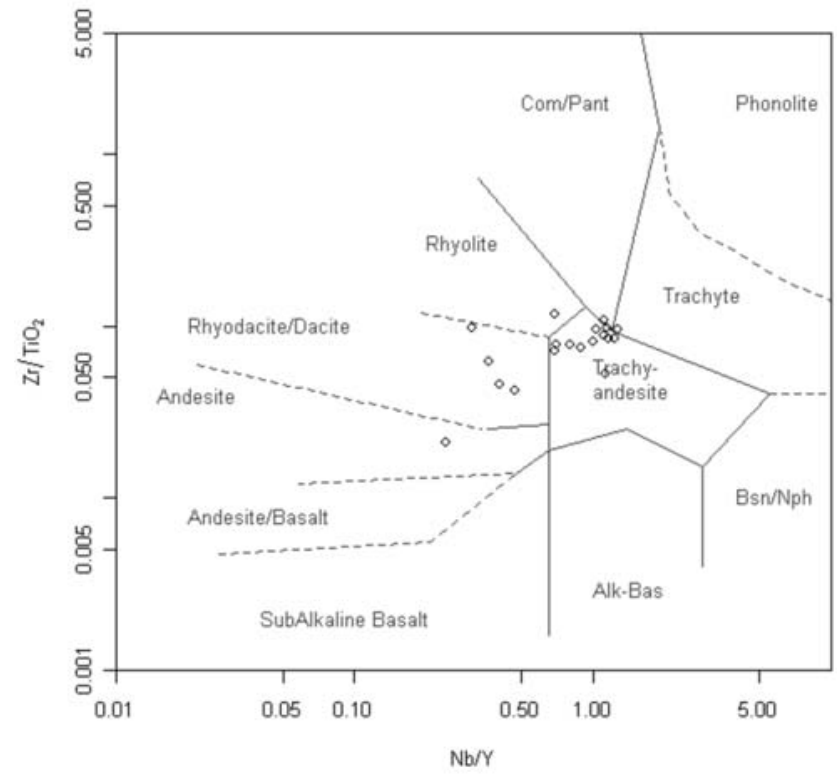

Fig. 5: $\mathrm{Nb} / \mathrm{Y}$ vs. $\mathrm{Zr} / \mathrm{TiO}_{2}$ plot of XRF analyses of zeolitized materials from Metaxades, Evros, Greece. Diagram by Winchester and Floyd (1977). Data from Koutles et al. (1995).

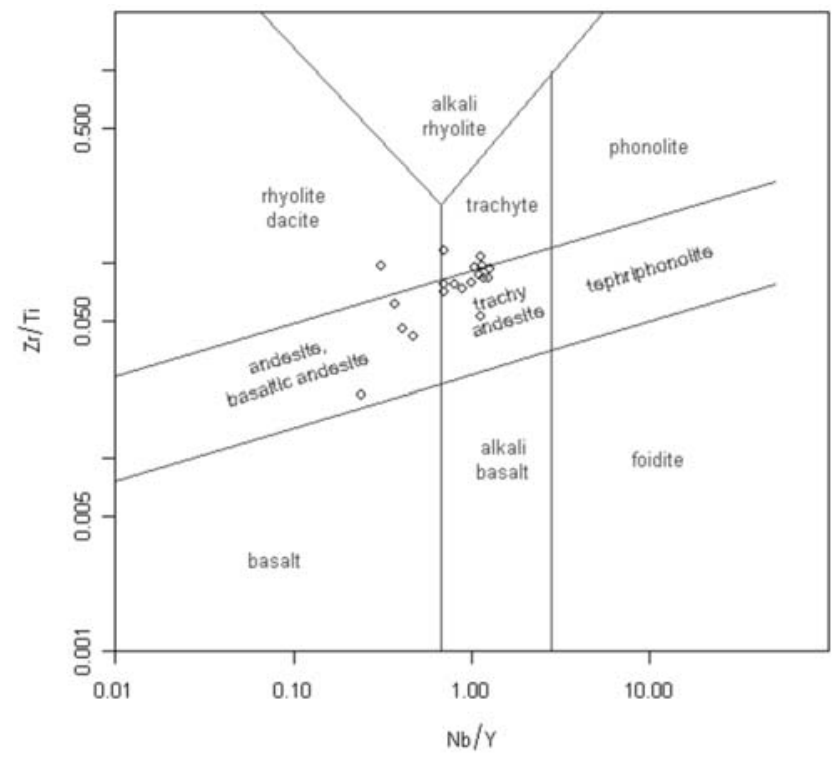

Fig. 6: $\mathrm{Nb} / \mathrm{Y}$ vs. Zr/Ti plot of XRF analyses of zeolitized materials from Metaxades, Evros County, Greece. Diagram by Winchester and Floyd (1977), as modified by Pearce (1986). Data from Koutles et al. (1995). 


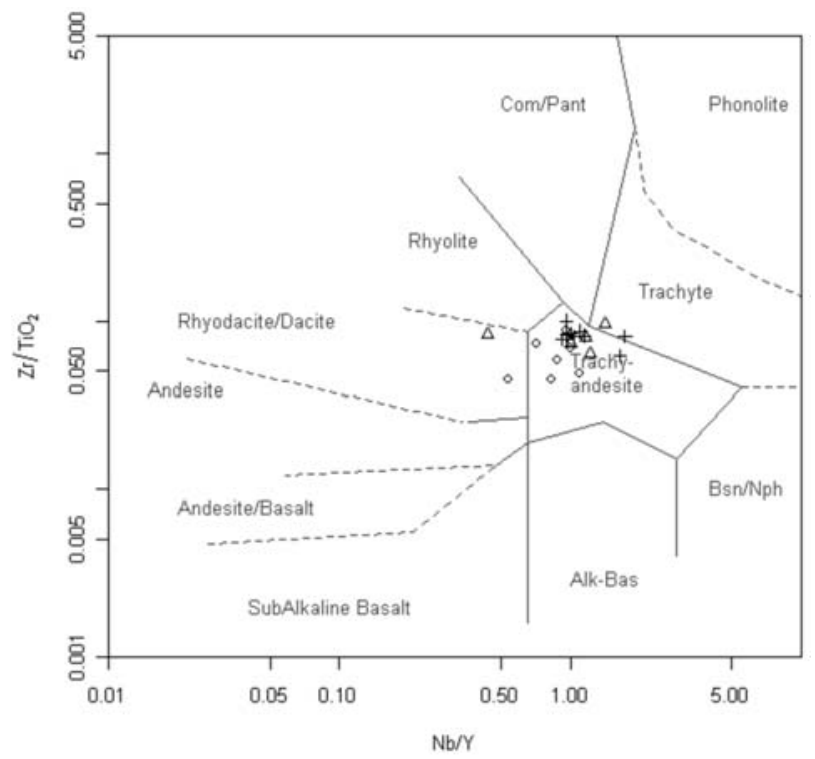

Fig. 7: $\mathrm{Nb} / \mathrm{Y}$ vs. $\mathrm{Zr} / \mathrm{TiO}_{2}$ plot of $\mathrm{XRF}$ analyses of zeolitized materials from Pentalofos, Palestra and PetrotaPaleochorofa area. Diagram by Winchester and Floyd (1977). Data from Stamatakis et al. (1998).

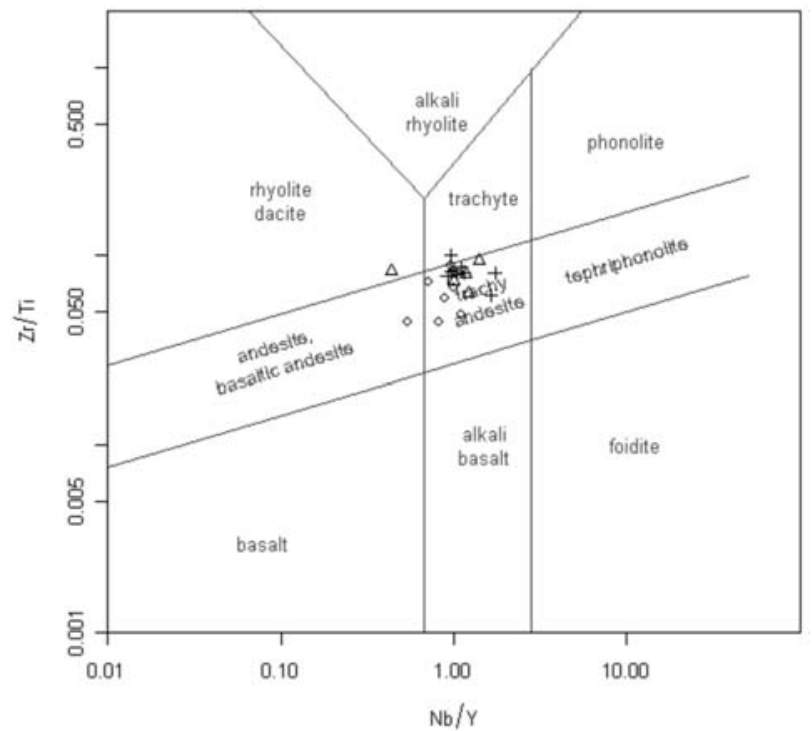

Fig. 8: $\mathrm{Nb} / \mathrm{Y}$ vs. $\mathrm{Zr} / \mathrm{TiO}_{2}$ plot of $\mathrm{XRF}$ analyses of zeolitized materials from Pentalofos, Palestra and PetrotaPaleochorofa area. Diagram by Winchester and Floyd (1977), as modified by Pearce (1986). Data from Stamatakis et al. (1998). 


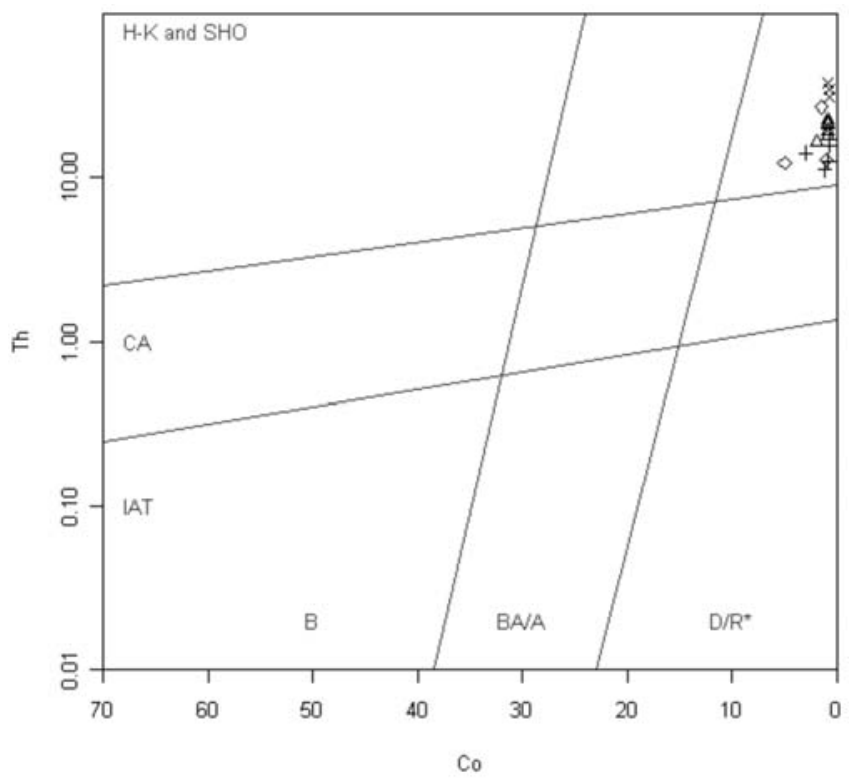

Fig. 9: Th - Co plot of XRF analyses of zeolitized materials on the diagram by Hastie et al. (2007). B, basalt; $\mathrm{BA} / \mathrm{A}$, basaltic andesite and andesite; $\mathrm{D} / \mathrm{R}^{*}$, dacite and rhyolite $(*$ indicates that latites and trachytes also fall in the D/R fields). IAT, island arc tholeiite; CA, calc-alkaline; H-K, high-K calc-alkaline; SHO, shoshonite. +: Dadia-Lefkimi, $\Delta$ : Metaxades, X: Petrota, $\diamond$ : Ferres.

In both diagrams the spreads, in terms of both the differentiation and the alkalinity indexes, and subsequently of the rock types of the precursor material, are notable. By taking into consideration the fact that there is no evidence in the area of the influence of a significant heavy alteration procedure, for example post hydrothermal events, it seems that these spreads, which come from a single pyroclastic unit with a vertical examined thickness of $100 \mathrm{~m}$, are to be questioned. Nb shows a mean value of 24.79 (s.d. 6.24), Zr 68.63 (s.d. 8.18), and Y 33.95 (14.31) respectively.

Stamatakis et al examined the geochemistry of zeolitized outcrops from the Pentalofos-PalaistraPetrota area. In this case the plots in the Winchester and Floyd (1977) and the one modified by Pearce (1986) are clearly showing an almost single parent precursor (Figs 7, 8).

A quite important diagram used to identify rock types and volcanic series of volcanic are rocks is the $\mathrm{K}_{2} \mathrm{O}-\mathrm{SiO}_{2}$ diagram, which however is highly susceptible to the effects of alteration. Working with altered volcanic island arc rocks Hastie et al. (2007) have developed a similar diagram by using Th as a proxy for $\mathrm{K}_{2} \mathrm{O}$ and $\mathrm{Co}$ as a proxy for $\mathrm{SiO}_{2}$ with a classification success rate of about $80 \%$. They also claimed that they managed to identify the volcanic series of initially hydrothermally altered, then tropically weathered, Cretaceous volcanic arc lavas from Jamaica. There was no indication from the bibliography that the diagram has been ever used with zeolitized volcanics and certainly has not been applied to such materials from Greece. The use of Th and Co has been proved extremely successful with heavily altered, by tropical weathering, hydrothermal and metamorphic processes, lavas comprising of basalts and dacitic tuffs (Hastie et al., 2008; Hastie and Kerr, 2010) as well as in calc-alkaline and alkaline magma mixing geo-petrological terrains (Luhr et al., 2010). 
In this case it becomes apparent (Fig. 9) that the rock type of the precursor of the zeolitized material studied is narrowed down to the field of dacites/rhyolites. This is coinciding with the finding of the initial Winchester and Floyd diagram. However, the Hastie diagram also reveals a degree of progression of a almost calc-alkaline to a high-K calc alkaline affinity of the parental volcanic materials.

\section{Acknowledgments}

The author has been always grateful to the Academic, Technical and Clerical Staff of the Geology Department of Leicester University for their kind host and constant support for almost two decades now. For their master knowledge and their valuable help with the analytical work and the data handling and interpretation, Nick Marsh, Rob Wilson, Rob Kelly, Rod Branson and Collin Cunningham should be specially mentioned. On 14/7/2007 Dr. Tim Brewer was suddenly lost for ever. I shall always remember and be grateful to Tim for proposing and setting up a Fellowship, so I can be able to continue my work in Leicester.

\section{References}

Djourova, E., and Aleksiev, B., 1995. Zeolitic rocks in the Northeastern Rhodopes. In: Aleksiev, B (Ed.), An Excursion to selected Zeolite and Clay deposits in the Eastern Rhodopes. A Guide to the post-Meeting trip, Sofia Zeolite Meeting '95, 20-30.

Finlow-Bates, T., and Stumpfl,E. F., 1981. The behaviour of so-called immobile elements in hydrothermally altered rocks associated with volcanogenic submarine-exhalative ore deposits. Mineralium Deposita 16,319-328.

Hastie, A.R., Kerr, A.C., Pearce, J.A., \& Mitchell, S.F., 2007. Classification of altered volcanic island arc rocks using immobile trace elements: development of the Th-Co discrimination diagram. Journal of Petrology 48, 2341-2357.

Hastie, A.R., Kerr, A.C., Mitchell, S.F., \& Millar, I.L., 2008. Geochemistry and petrogenesis of Cretaceous oceanic plateau lavas in eastern Jamaica. Lithos, 101, 323-343.

Hastie, A.R., and Kerr, A.C., 2010. Mantle plume or slab window?: Physical and geochemical constraints on the origin of the Caribbean oceanic plateau. Earth Science Reviews, 98, 283-293.

Jochum, K.P., Nohl, U., Herwig, K., Lammel, E., Stoll, B., \& Hofmann, A.W., 2005. GeoRem: A new geochemical database for reference materials and isotopic standards. Geostandards \& Geoanalytical Research 29, 333-338.

Kirov, G., Fillipides, A., Tsirambides, A., Tzvetanov, R., \& Kassoli-Fournaraki, A., 1990. Zeolite bearing rocks in Petrota area (Eastern Rhodope Massif, Greece). Geologica Rhodopica 2, 500-511.

Kitsopoulos, K. P., 1991. Volcanic zeolitic tuffs from Greece as an industrial commodity. Useful properties and possible applications. University of Leicester, MSc Thesis, $110 \mathrm{pp}$.

Kitsopoulos, K. P., Scott, P.W., Jeffrey, C.A., \& Marsh, N.G,, 2001. The mineralogy and geochemistry of zeolite-bearing volcanics from AkrotiriI (Santorini island) and Polyegos (Milos group of islands) Greece. Implications for geochemical classification diagrams. Bulletin of the Geological Society of Greece, vol. XXXIV/3, Proceedings of the 9th International Congress, Athens, 859-865.

Koutles, Th., Kassoli-Fournaraki, A., Filippidis, A., \& Tsirambides, A., 1995. Geology and geochemistry of the Eocene zeolite-bearing volcaniclastic sediments of Metaxades, Thrace, Greece. Estudios Geologicos, 51, 19-27.

Le Bas, M.J., Le Maitre, R.W., Streckeisen, A., \& Zanettin, B., 1986. A chemical classification of volcanic rocks based on the total alkali-silica diagram. Journal of Petrology, 27, 745-750.

Le Bas,M. J., Le Maitre, R.W., \& Woolley, A. R. (1992).The construction of the total alkali-silica chem- 
ical classification of volcanic rocks. Mineralogy and Petrology, 46, 1-22.

Le Maitre, R. W., Bateman, P., Dudek, A., Keller J., Lameyre, J., Le Bas, M. J., Sabine, P. A., Schimd, R., Sorensen, H., Strckeisen, A., Woolley, A. R., \& Zanettin, B., 1989. A classification of igneous rocks and glossary of terms. (Blackwell, Oxford).

Luhr, J. F., Ochoa, C. N., and Savov, I.P., 2010. Tephrochronology, petrology and geochemistry of LateHolocene pyroclastic deposits from Volcán de Colima, Mexico. Journal of Volcanology and Geothermal Research, doi:10.1016/j.jvolgeores.2009.11.007

Marantos, I., Kosharis, G., Perdikatsis, V., \& Karantassi, S., 2000. Study on the zeolitic tuffs of Skaloma Area, Rodopi Prefecture, Thrace. Internal Report, I.G.M.E., Athens, 56 pp.

Marantos, I., Koshiaris, G., Karantassi, S., Perdikatsis, V., and Christidis, G., 2004. Preliminary study of altered Tertiary volcaniclastic rocks in the area of Asproula, Nea Santa, Rodopi perfecture, Thrace, NE Greece. Bulletin of the Geological Society of Greece, 35, 454_463.

Marchev, P., Raicheva, R., Downes, H., Vaselli, O., Chiaradia, M., \& Moritz, R., 2004. Compositional diversity of Eocene-Oligocene basaltic magmatism in the Eastern Rhodopes, SE Bulgaria: implications for genesis and tectonic setting. Tectonophysics, 393, 301-328.

Pearce, J. A., 1996. A user's guide to basalt discrimination diagrams. In: Wyman, D. A. (ed.) Trace Element Geochemistry of Volcanic Rocks: Applications for Massive Sulphide Exploration. Geological Association of Canada, Short Course Notes 12,79-113.

Peccerillo, R. and Taylor, S. R., 1976. Geochemistry of Eocene calc-alkaline volcanic rocks from the Kastamonu area, northern Turkey. Contributions to Mineralogy and Petrology, 58, 63-81.

Rickwood, P. C., 1989. Boundary lines within petrologic diagrams which use oxides of major and minor elements. Lithos, 22, 247-263.

Skarpelis, N., Marantos, I., \& Christidis, G., 1993. Zeolites in Oligocene volcanic rocks, Dadia-Lefkimi area, Thrace, Northern Greece: mineralogy and cation-exchange properties. Bulletin of the Geological Society of Greece, 28, 305.

Stamatakis, M., Hall, A., Lutat, U., \& Walsh, J.N., 1998. Mineralogy, origin and commercial value of the zeolite-rich tuffs in the Petrota-Pentalofos area, Evros county, Greece. Estudios Geologicos, 54, 3-15.

Tsirambides, A., Kassoli-Fournaraki, A., Filippidis, A., \& Soldatos, K., 1989. Preliminary results on clinoptilolite containingvolcani clastic sediments from Metaxades area, NE Greece. Bulletin of the Geological Society of Greece, 23, 451-460.

Tsolis-Katagas, P., and Katagas, C., 1990. Zeolitic diagenesis of Oligocene pyroclastic rocks of the Metaxades area, Thrace, Greece. Mineralogical Magazine, 54, 95-103.

Winchester, J. A., and Floyd, P. A., 1977. Geochemical discrimination of different magma series and their differentiation products using immobile elements. Chemical Geology, 20, 325-343.

Yanev, Y., Innocenti, F., Manetti, P., \& Serri, G., 1998. Upper Eocene - Oligocene collision - related volcanism in Eastern Rhodopes (Bulgaria ) - Western Thrace (Greece): Petrogenetic Affinity and Geodynamic Significance. Acta Vulganologica, 10 (2), 279 - 291. 